\title{
MANAJEMEN SISTEM INFORMASI DALAM KEGIATAN PENERIMAAN SANTRI BARU DI PONDOK PESANTREN PUTERI KHADIJAH PAMEKASAN
}

\author{
Ika Herliana, Hilmi Qosim Mubah, dan Ahmadi \\ IAIN Madura, IAIN Madura, dan STAI Al-Hamidiyah \\ Email:ikaherliana2@gmail.com, hilmiqosimmubah@iainmadura.ac.id,dan \\ stamidya@gmail.com
}

\begin{abstract}
Abstrak
Penelitian ini bertujuan untuk mengetahui pengelolaan sistem informasi, faktor pendukung dan penghambat dalam penerimaan santri baru di Pondok Pesantren Puteri Khadijah Pamekasan. Penelitian ini menggunakan pendekatan kualitatif dengan jenis penelitian deskriptif. Data diperoleh dari observasi, wawancara, dan dokumetasi. Hasil penelitian menunjukkan bahwa pertama dalam melakukan pengolalaan sistem informasi penerimaan santri baru di pondok pesantren tersebut melakukan perencanaan dengan membentuk panitia, menentukan tanggal buka dan tutup, syaratsyarat yang harus dipenuhi, menyediakan formulir dan penyetoran berkas berbasis website serta melakukan evaluasi dari setiap proses yang sudah dilakukan secara langsung ataupun secara tertulis setelah seluruh program terlaksana dengan adanya evaluasi tersebut tentunya untuk mengetahui apa saja yang masih kurang dari kinerja ke panitian penerimaan santri baru kemudian diperbaiki dimasa yang akan datang. Kedua, Faktor pendukung adalah adanya bimbingan dari pengasuh, arahan dari pembina dan juga kerja sama panitia Penerimaan Santri Baru, kelengkapan sarana dan prasarana. Faktor penghambatnya adalah kurangnya komunikasi antar sesama panitia Penerimaan Santri Baru.
\end{abstract}

Kata Kunci : Pengelolaan, Sistem Informasi, penerimaan santri baru

\begin{abstract}
This study aims to determine the management of information systems, supporting and inhibiting factors in the acceptance of new students at the Puteri Khadijah Islamic Boarding School Pamekasan. This study uses a qualitative approach with a descriptive type of research. Data obtained from observation, interviews, and documentation. The results showed that first, in managing the information system for admitting new students at the Islamic boarding school, they planned by forming a committee, determining the opening and closing dates, the conditions that must be met, providing website-based forms, and file deposits and evaluating each process carried out. This has been done directly or in writing, after the entire program has been carried out with the evaluation, of course, to find out what is still lacking from the performance to the new student admissions committee then corrected in the future. Second, the supporting factors are the guidance from the caregivers, the direction from the coaches, and also the cooperation of the New Santri Admission committee, completeness of facilities, and infrastructure. The inhibiting factor is the lack of communication between fellow New Santri Admission committees.
\end{abstract}

Keywords : Management, information system, new student admission 


\section{PENDAHULUAN}

Manusia adalah mahkluk sosial. Karenakan manusia adalah mahkluk yang membutuhkan komunikasi dan interaksi antara satu dengan yang lainnya. Informasi yang diperoleh ada yang bermanfaat bahkan mungkin infomasi juga ada yang tidak bermanfaat. Informasi yang berguna di antaranya dapat bermanfaat untuk 1) menambah pengetahuan bagi setiap individu, 2) mengurangi ketidakpastian terutama pada saat akan membuat perencanaan atau pengambilan keputusan pendidikan, 3) memberikan standar, patokan, aturan, atau ukuran dalam pelaksanaan kegiatan, 4) mengurangi resiko kegagalan. Setiap manusia membutuhkan informasi dan memiliki informasi.Hanya saja ada informasi yang berisi data yang benar-benar dibutuhkan untuk langsung diaplikasikan, ada juga informasi yang belum memiliki nilai manfaat. ${ }^{1}$

Semua fungsi manajemen dalam lembaga pendidikan (lembaga pendidikan islam khususnya) akan terlaksana dengan baik apabila di dalamnya terdapat sistem informasi yang dikelola tepat. Hal itu, sangat diperlukan untuk perencanaan, pengambilan keputusan, dan pengendalian. Dalam sebuah lembaga pendidikan terdapat pengelolaan informasi yang tepat karena seoarang manajer atau penanggung jawab pendidikan harus mampu mewujudkan impian (tujuan pendidikan) menjadi kenyataan. ${ }^{2}$

Informasi merupakan sejumlah keterangan yang diolah menjadi bentuk yang lebih berguna dan lebih berarti bagi penerimanya, dalam perkembangan zaman, informasi juga memberikan dampak yang cukup signifikan terhadap dunia pendidikan. ${ }^{3}$ Salah satu hal penting yang dapat mempertahankan dan mengembangkan sebuah lembaga pendidikan adalah pengelolaan sistem informasi yang tepat.Pengelolaan suatu informasi dalam institusi atau lembaga pendidikan merupakan bagian dari sistem pendidikan itu sendiri.Informasi yang dikelola dengan baik hendaknya berada dalam suatu sistem pengelolaan informasi.Informasi yang dikelola dengan baik dalam suatu sistem dikenal dengan istilah sistem informasi manajemen.Sementara sistem informasi manajemen yang diterapkan dalam lembaga pendidikan disebut sistem informasi manjemen pendidikan.

Sistem informasi manajemen pendidikan merupakan sistem informasi yang berfungsi untuk mengelola informasi pendidikan. Keterlibatan sistem infomasi manajemen pendidikan salah satunya adalah untuk menunjang efesiensi dan efektifitas kegiatan dan layanan pendidikan dan bertujuan juga untuk meningkatkan kelancaran aliran informasi, kontrol kuliatas, dan kerja sama dengan pihak lain. Penerapan sistem informasi manajemen harus didasarkan pada informasi dari tingkat manajemen, dukungan operasi dan manajemen, serta keunggulan strategis. Sistem informasi harus mempunyai sifat pemprosesan informasi yag efektif, manajemen informasi yang efektif keluwesan, dan kepuasan pengguna.

Sistem Informasi manajemen Pendidikan menjadi bahasan yang membantu manusia untuk menuju tujuan pendidikan itu sendiri.Tujuan pendidikan itu sendiri adalah agar manusia dapat menjalani kehidupan, cerdas, dan memilki keterampilan sehingga dapat hidup mandiri serta bertanggung jawab tidak hanya untuk dirinya sendiri melainkan juga keluarga, masyarakat, dan lingkungan sekitar.

\footnotetext{
${ }^{1}$ Helmawati, Sistem Informasi Manajemen Pendidikan Agama Islam (Bandung: Remaja Rosdakarya, 2015), 53

${ }^{2}$ Helmawati, 1.

${ }^{3}$ Jeperson Hutahaen, Konsep Sistem Informasi (Yogyakarta: Deepublish, 2015), 9.
} 
Tujuan dari sistem Informasi Manajemen Pendidikan adalah untuk memenuhi kebutuhan informasi bagi pimpinan organisasi dan subunit organisasi yang ada di dalamnya.Pada awalnya teknologi pendidikan dipandang hanya berperan pada taraf pelaksanaan kurikulum dikelas.sementara konsep baru muncul dan menghendakin teknologi pendidikan sebagai masukan, bahkan sejak tahap perencaan kurikulum. ${ }^{4}$

Menurut Undang-Undang No 18 Tahun 2019 tentang Pesantren "Pesantren adalah institusi berbasis masyarakat dan didirikan oleh perorangan, yayasan, organisasi masyarakat islam dan/atau masyarakat yang menanamkan keimanan dan ketakwaan kepada Allah Swt, memupuk akhlak mulia serta memegang teguh ajaran Islam rahmatan lil'alamin yang tercermin dari sikap rendah hati, toleran keseimbangan, moderat, dan nilai luhur bangsa Indonesia lainnya melalui pendidikan, dakwah Islam, keteladanan, dan pemberdayaan masyarakat dalam kerangka Negara Kesatuan Rebuplik Indonesia. $^{5}$

Lembaga pendidikan islam yang paling variatif adalah pesantren. Keberadaan pondok pesantren sebagai lembaga pendidikan islam tertua di Indonesia telah berkembang sejak masa penyebaran Islam dan telah banyak berperan dalam mencerdaskan kehidupan masyarakat. Sejalan perkembangan pondok pesantren menunnjukkan bahwa lembaga ini tetap eksis dan konsisten sehingga dari pesantren lahirlah para kader ulama, guru agama, mubalig yang sangat dibutuhkan di masyarakat.

Pesantren juga memadukan pendidikan aqliyah, ruhiyah,danjasadiyah.Artinya, berupaya mendidik peserta didik menjadi anak yang berkembang kemampuan akal dan intelektual, meningkatnya kualitas keimanan dan ketakwaan kepada Allah SWT, terbina ahklak yang berbudi mulia. ${ }^{6}$ Upaya untuk meningkatkan suatu kualitas dan prestasi pada pesantren di perlukan adanya manajemen peserta didik. Adapun tujuan dari manajemen peserta didik ini mengatur kegiatan peserta didik agar kegiatan tersebut dapat membantu proses pembelajaran di lembaga pesantren tersebut. Sehingga nantinya dapat memberikan kontribusi bagi pencapaian tujuan lembaga pesantrennya. Dan manajemen peserta didik harus di kelola dengan baik dan benar agar dapat bersaing dengan lembaga pendidikan lainnya. ${ }^{7}$

Santri itu berasal dari perkataan "sastri" sebuah dari kata dari Sansekerta, yang artinya melek huruf, dikonotasikan dengan kelas literary bagi orang jawa yang disebabkan karena pengetahuan mereka tentang agama melalui kitab-kitab bertuliskan dengan bahasa arab. Kemudian diasumsikan bahwa santri berarti orang yang tahu tentang agama melalui kitab-kitab berbahasa arab dan paling tidak santri bisa membaca Al-quran, sehingga membawa kepada sikap lebih serius dalam memandang agama. Juga perkataan santri berasal dari bahasa Jawa "cantrik" yang berarti orang yang selalu mengikuti guru kemana guru pergi menetap (istilah pewayangan) tentunya dengan tujuan agar dapat belajar darinya mengenai keahlian tertentu.

\footnotetext{
${ }^{4}$ Donni Juni Priansa, Manajemen Dan Supervisi Pendidikan (Bandung: CV. Pustaka Setia, 2018), 41.

${ }^{5}$ Hilmi Qosim Mubah, Manajemen Pesantren Dan Pendidikan Luar Sekolah (Pamekasan: iainmadura press, 2019), 55.

6 Juju Saepudin, "PENDIDIKAN AGAMA ISLAM PADA SEKOLAH BERBASIS PESANTREN: STUDI KASUS PADA SMP AL MUTTAQIN KOTA TASIKMALAYA," EDUKASI: JURNAL PENELITIAN PENDIDIKAN AGAMA DAN KEAGAMAAN 17, no. 2 (2019): 177, http://jurnaledukasikemenag.org.

${ }^{7}$ Jaja Jahari and Heri Khoiruddin, "Manejemen Peserta Didik," Jurnal ISEMA (Islamic Education Management) 3, no. 2 (2018): 1, https://journal.uinsgd.ac.id/index.php/isema/article/view/5009/2789.
} 
Penerimaan santri baru (PSB) merupakan suatu proses adminitrasi untuk seleksi calon santri baru. Proses PSB dilakukan secara manual maupun memanfaatkan teknologi yang sudah berkembang pada saat ini pada masing-masing instansi sekolah khususnya pondok pesantren. ${ }^{8}$ Penerimaan santri baru merupakan peristiwa penting bagi lembaga, karena peristiwa ini merupakan titik awal yang menentukan kelancaran tugas lembaga.Kesalahan dalam penerimaan santri baru dapat menentukan sukses tidaknya sebuah pendidikan di dalam lembaga. ${ }^{9}$ Salah satu kegiatan yang pertama dilakukan yang biasanya dengan melakukan seleksi calon santri. Ada beberapa langkahlangkah penerimaan sanrti baru pada garis besarnya adalah sebagai berikut: a. Membentuk panitia, b. Menentukan syarat pendaftaran calon, c. Menyediakan formulir pendaftaran, d. Pengumuan pendaftaran calon, e. Menyediakan buku pendaftaran, f. Waktu pendaftaran, g. Penentuan calon yang diterima.

Pondok Pesantren puteri khadijahadalah salah satu lembaga pendidikan yang berbasis agama yang ada di kota pamekasan, pesantren ini didirikan oleh Bapak Dr. Buna'i, S.Ag, M.Pd sebagai pengasuh pada tanggal 14 juli 2008 kemudian diresmikan pada tanggal 1 April 2009 dan terdapat struktur kepemipinan di dalamnya, yang terdiri dari dewan kosultan, pengurus, dan anggota pondok.

Pesantren sebagai wadah untuk menuntut ilmu agama islam, maka diperlukan adanya pengembangan dalam pengelolaan dalam menajemen agar tetap bisa mengikuti perkembangan zaman. SIM pada pondok pesantren memerlukan perkembangan agar dapat menyajikan keseluruhan data, baik dari kepengurusan, santri, dana madrasah dan pondok. ${ }^{10}$ Begitu pula yang terjadi dan di praktekan di pondok pesantren puteri khadijah Pamekasan. Setiap individu yang akan mendaftarkan diri menjadi sanri di pondok pesantren puteri khadijah harus mengikuti serangkaian persyaratan yang sudah ditetukan oleh pihak panitia.

Kegiatan penerimaan santri baru yang dilakukan di pondok pesantren puteri khadijah Pamekasan meliputi beberapa tahapan : pertama penyebaran brosur. Pada penyebaran brosur ini yang menyebarkannya adalah panaitia santri baru.Kedua adalah tahap pengisian formolir, pada tahap ini calon santri wajib mengisi form yang sudah ditetapkan oleh pengasuh pondok pesantren khadijah tersebut. Ketiga penyetoran berkas-berkas, pada tahap ini calon santri wajib mengumpulkan berkas yang berupa : a) Foto 3x4 2 lembar, b) Fotocopy kartu keluarga (KK), c) Surat pernyataan santri, d) Surat pernyataan orang tua/wali santri. Keempat yaitu cabisan atau bertamu kepada pengasuh. Dan terakhir yaitu tahap orientasi ke-APK-an pada tahap ini bertujuan agar parasantri nantinya mengerti dan mentaati segala peraturan yang berlaku di pondok pesantren puteri khadijah pamekasan.

Setiap calon santri baru diwajibkan untuk mengikuti sejumlah atau serangkaian tes yang telah ditetapkan oleh pesantren pondok puteri khadijah, yang diantaranya

8 Aneu Yulianeu and Muhamad Sodik, "Perancangan Sistem Informasi Penerimaan Santri Baru Di Pondok Pesantren Sukamanah,” Jurnal Manajemen Informatika 6, no. 2 (2019): 21.

9 Adi Wibowo, "INTEGRASI MANAJEMEN KESISWAAN PENDIDIKAN FORMAL DAN NON FORMAL DI PONDOK PESANTREN AN-NAWAWI BERJAN PURWOREJO," Jurnal ISEMA (Islamic Education Management) 4, no. 2 (2019): 222.

10 Ahmad Bagus Setiawan and Juli Sulaksono, "Sistem Informasi Manajemen Santri Di Pondok Pesantren Al Ishlah Kota Kediri," Network Engineering Research Operation 4, no. 2 (2019): 81, https://doi.org/10.21107/nero.v4i2.122. 
berupa tes baca tulis Al-quran, tes tulis bahasa arab dan bahasa inggris, dan juga tes praktek sholat. Tujuan dari diadakannya beberapa tes tersebut adalah menentukan kelas diniyah di pondok pesantren puteri khadijah. Selain itu, para santri pondok pesantren puteri khadijah juga akan mendapatkan fasilitas ilmu tambahan yang tidak dapat di bangku perkuliahan seperti kemampuan berkomunikasi menggunakan dua bahasa asing, pembelajaran kitab kuning, serta mengasah bakat yang dimiliki oleh setiap santri.

Dalam hal ini sebagaimana yang dinyatakan oleh ketua pondok pesantren puteri khadijah pamekasan bahwa pengelolaan sistem informasi di pondok pesantren puteri khadijah yaitu melalui penyebaran brosur baik offline maupun online yang bekerja sama dengan pengurus pondok pesantren (PSB). Dalam hal ini pesantren mengupayakan agar brosur dapat menyebar secara luas sehingga calon santri baru bisa memperoleh informasi dari berbagai sumber.Selain itu, adanya alumni pesantren juga sangat mempengaruhi dalam penerimaan santri baru karena mereka juga berperan dalam mengajak adik ataupun keluarga untuk tinggal di pesantren.Karena sekarang sistemnya daring (dalam jaringan) dalam penerimaan mahasiswa baru maka ada plat form khusus dari pondok pesantren yang berupa link. Dimana calon mahasiswa baru ( santri) mengakses dan mnengsisi data di link tersebut.

Berdasarkan pengelolaan sistem informasi yang sekarang dengan sebelumnya sangat berbeda jauh yang dimana sekarang segala bentuk proses-proses penerimaan santri baru seperti penyebaran brosur dan persyaratan pendaftaran dilakukan secaran online dan tentunya hal tersebut diterima dengan baik oleh para pendaftar santri baru serta dapat memudahkan mereka dalam mendaftar serta mendapatkan informasi melalui media teknologi atau sistem online, hal ini tentunya sejalan dengan kemajuan teknologi pada saat ini. Berdasarkan hal tersebut sistem pengelolaan informasi yang menggunakan media teknologi justru dirasa lebih baik dan efesien dari pada pengelolaan sistem informasi yang sebelumnya. Baik dalam hal waktu, tempat, biaya, maupun tenaga. Tidak ketinggalan juga dengan sistem ini, para calon pendaftar santri baru dan wali santri tidak perlu bersusah payah untuk mendatangi Pondok Pesantren Puteri Khadijah Pamekasan untuk sekedar melihat informasi dan pengumuman yang berkaitan dengan pelaksanan penerimaan santri baru.

Berdasarkan konteks penelitian di atas maka peneliti tertarik untuk melakukan penelitian di Pondok Pesantren Puteri Khadijah, dengan mengambil judul Pengelolaan Sistem Informasi dalam Penerimaan Santri Baru di Pondok Pesantren Puteri Khadijah Pamekasan. Dengan fokus dan tujuan penelitian untuk mengetahui pengelolaan,sistem Informasi, faktor pendukung dan penghambat dalam penerimaan santri baru di Pondok Pesantren Puteri Khadijah Pamekasan.

\section{METODE PENELITIAN}

Pendekatan dalam penelitian ini menggunakan pendekatan kualitatif karena pendekatan ini dapat memudahkan peneliti untuk lebih dekat dengan subjek yang diteliti dan lebih peka terhadap apa yang terjadi di lapangan. Adapun jenis penelitian yang digunakan yaitu penelitian deskriptif karena dalam penelitian ini peneliti tidak melakukan apa-apa terhadap objek atau wilayah yang diteliti.

Lokasi dalam penelitian ini yaitu di Pondok Pesantren Puteri Khadijah Pamekasan yang merupakan yang ada di kota Pamekasan lebih tepatnya di Perumnas Tlanakan Indah. karena pengelolaan informasi manajemen yang digunakan melalui plat form 
khusus dari pondok pesantren yang berupa link yang mana Pondok Pesantren Puteri Khadijah ini yang hanya menerapkan hal tersebut dengan sangat terstruktur, sehingga peneliti tertarik untuk meneliti di lokasi.

Metode pengumpulan data dalam penelitian yaitu pertama observasi, dalam observasi ini, peneliti menggunakan observasi partisipan. Kemudian yang kedua adalah wawancara dalam penelitian ini, peneliti menggunakan wawancara semi terstruktur. Wawancara semi terstruktur adalah jenis wawancara yang dilakukan bersifat terbuka bahwa peneliti diberi kebebasan dalam bertanya dan mengatur alur atau setting wawancara. Yang terakhir pengumpulan data adalah dokumentasi. Dokumentasi dalam penelitian sebagai sumber data karena dalam banyak hal dokumen sebagai sumber data dimanfaatkan untuk menguji, menafsirkan, bahkan untuk meramalkan. ${ }^{11}$

Adapun teknik analisis data pada penelitian ini menggunakan analisis data ada tiga tahapan, yaitu pertama kondensasi data, dalam kondensasi data peneliti harus mampu menyeleksi seluruh data yang ada dilapangan serta mengumpulkan informasiinformasi yang berhubungan dengan penelitian. Kedua yaitu penyajian data, dengan menyajikan data maka akan memudahkan untuk memahami apa yang terjadi, merencanakan kerja selanjutnya berdasarkan apa yang telah di pahami yang terakhir adalah penarikan kesimpulan (verifikasi) dilakukan bisa menjawab dari setiap rumusan masalah yang telah ditetapkan sejak awal. ${ }^{12}$

\section{HASIL DAN PEMBAHASAN}

\section{Pengelolaan sistem informasi dalam penerimaan santri baru di Pondok Pesantren Puteri Khadijah Pamekasan}

Pengelolaan sistem dalam penerimaan santri baru di Pondok Pesantren Puteri Khadijah Pamekasanyaitu mengadakan planning terlebih dahulu, diadakannya planning ini diharapkan memperlancar suatu acara yang akan berlangsung. Yang mana dalam melaksanakan program penerimaan santri baru antara pengasuh, pembina, dan juga panitia penerimaan santri baru merupakan orang yang bertanggung jawab dan penentu dalam kegiatan penerimaan santri baru tersebut.Dalam hal tersebut mereka sudah mempunyai program kerja masingmasing yang sudah ditetapkan. Kerja sama yang baik antara pengasuh, pembina dan panitia penerimaan santri baru yang menjadikan tercapainya proses kegiatan dalam penerimaan santri baru.

Sesuai dengan pendapat Anton Athoillah dalam bukunya mendefinisikan bahwa pengelolaan adalah "suatu proses yang terdiri atas tindakan-tindakan perencanaan, pengorganisasian, kepemimpinan dan pengendalian yang didalamnya terdapat upaya anggota organisasi untuk mencapai tujuan yang telah ditetapkan dengan mengarahkan sumber daya organisasi yang dimiliki. ${ }^{13}$

Terkait perencanaan penerimaan santri baru dimulai dari pembentukan panitia penerimaan santri baru biasanya mengenai pembentukan panitia pengasuh Pondok Pesantren Puteri Khadijah Pamekasan meminta bantuan pengurus khususnya bagian inti untuk memilih siapa saja yang layak dan bersedia untuk dijadikan panitia. Pada bagian ini pengurus pondok menyeleksi calon-calon PSB dengan cara

\footnotetext{
${ }^{11}$ Lexy J. Moleong, Metodologi Penelitian Kualitatif (Bandung: Remaja Rosdakarya, 2016), 217.

${ }^{12}$ Moleong, 124.

${ }^{13}$ Anton Athoilla, Dasar-Dasar Manajemen (Bandung: CV Pustaka Setia, 2010), 13.
} 
melihat kesehariannya mereka seperti tingkah laku mereka terhadap kakak tingkat ataupun adek tingkat. Setelah itu, pengurus pondok mengajukan nama-nama yang akan di jadikan PSB kepada bapak pengasuh, kemudian pihak pengurus menunggu keputusan dari bapak pengasuh. Jika sudah ada keputusan dari pengasuh kemudian PSB tersebut dilantik dan diberikan amanah oleh bapak pengasuh.

Penentuan ditetapkannya kapan tanggal dibukanya pendaftaran hingga ditutupnya pendaftaran santri baru. Sesudah panitia penerimaan santri baru terbentuk kemudian melakukan rapat antara pengasuh dengan panitia penerimaan santri baru mengenai penentuan ditetapkannya kapan tanggal dibukanya pendaftaran hingga kapan ditutupnya pendaftaran santri baru tersebut dalam penentuan tersebut yang sudah mengatur dari kapan tanggal pendaftaran penerimaan santri baru itu dibuka hingga sampai kapan tanggal pendaftaran penerimaan santri baru itu ditutup yaitu dari pengasuh Pondok Pesantren Puteri Khadijah Pamekasan itu sendiri, sedangkan panitia penerimaan santri baru hanya menjalankan sesuai arahan yang sudah diatur oleh pengasuh Pondok Pesantren Puteri Khadijah Pamekasan.

Menentukan syatar-syarat yang dibutuhkan dalam pendaftaran penerimaan santri baru dalam hal ini panitia menyuruh kepada calon santri untuk mengumpulkan berkas-berkas pendaftaran yang sudah di tetapkan oleh pondok pesantren puteri khadijah. Yang berupa : a) Mengisi formulir melalui link b) Membayar adminitrasi pembayaran. c) Mengisi surat pernyataan d) Menyerahkan pas foto warna 3x4 2 lembar. e) Menyerahkan fotocopy akta kelahiran 1 lembar. f) Menyerahkan foto copy kartu keluarga (KK). g) Menyerahkan fotocopy KTP kedua orang/walisantri masing-masing 1 lembar.

Jadi dari beberapa syarat-syarat tersebut harus dipenuhi oleh para calon santri baru karena hal tersebut merupakan persyaratan yang diwajibkan untuk mendaftar bagi para calon santri baru yang mendaftar di Pondok Pesantren Puteri Khadijah Pamekasan.

Tentunya dari beberapa hal di atas ini sesuai dengan pernyataan Hamdan dalam tulisannya yang mengatakan bahwa langkah-langkah penerimaan santri baru pada garis besarnya adalah a. pembentukan panitia penerimaan santri baru, $b$. menentukan syarat pendaftaran calon santri baru, c. menyediakan formulir pendaftaran, d. pengemuman calon pendaftaran calon santri baru, e. menyediakan buku pendaftaran, $\mathrm{f}$. waktu pendaftaran yang diterima. ${ }^{14}$

Menyebarkan brosur dengan menggunakan dua metode yang pertama, penyebaran secara langsung, kedua, dilakukan secara online.Dalam menyebarkan brosur dengan menggunakan dua metode, penyebaran secara langsung atau offline yang mana dalam penyebaran ini panitia menyebarkan brosur di kampus dan sekitarnya. Sedangkan penyebaran brosur secara online untuk panitia penerimaan santri baru menggunakan sosial media baik itu instagram dan whatsapp.

Menyediakan formulir pendaftaran dan penyetoran berkas-berkas yang berbentuk website. Karena sistem yang dipakai dalam pengelolaan penerimaan santri baru berbeda dengan tahun sebelumnya, kalau pada tahun sebelumnya ketika

14 Hamdan Hamdan, "Pengelolaan Santri Di Sekolah Menengah Atas Pondok Pesantren Modern AlIkhlas Lubuklinggau," Journal Of Administration and Educational Management (ALIGNMENT) 1, no. 2 (2018): 108, https://doi.org/10.31539/alignment.v1i2.346. 
pendaftaran serta dalam penyetoran berkas-berkas para calon pendaftaran diharuskan dating langsung ke Pondok Pesantren Puteri Khadijah Pamekasan akan tetapi kalau sekarang berbeda seperti yang kita ketahui dikarenakan pada saat ini masih pandemi dimana kita dituntut untuk mematuhi protokol kesehatan yang sudah ditetapkan oleh pemerintah maka oleh sebab itu dalam pendaftaran hingga penyetoran berkas-berkas bagi para calon santri baru disetorkan melalui website yang sudah disediakan oleh panitia penerimaan santri baru tanpa harus datang ke Pondok Pesantren Puteri Khadijah Pamekasan.

Penyerahan santri baru dari wali santri kepada pengasuh pondok pesantren puteri khadijah Pamekasan.Dalam penyerahan santri ini dikenal dengan cabisan oleh para santri pondok pesantren puteri khadijah.Dimana cabisan (silaturrahmi) antara wali santri dengan pengasuh Pondok Pesantren Putri Khadijah Pamekasan sekaliguspenyerahan dari wali santri kepada pengasuh pondok pesantren puteri khadijah Pamekasan.

Pelaksanaan orientasi ke APK an yang diikuti oleh santri baru dan panitia penerimaan santri baru. Dimana dalam orientasi ini Pondok Pesantren Puteri Khadijah Pamekasan biasa menyebut dengan ke APK an, yang mana pada kegiatan ke APK an ini merupakan kegiatan tahap pengenalan entah itu kegiatan-kegiatan pembelajarannya sampai peraturan-peraturan yang ada di Pondok Pesantren Puteri Khadijah Pamekasan.

Hal di atas sesuai dengan pernyataan Muhammad Khoirul Umamdalam tulisannya bahwa orientasi peserta didik adalah kegiatan penerimaan peserta didik baru dengan mengenalkan situasi dan kondisi lembaga pendidikan, tempat peserta didik itu menempuh pendidikan. Tujuan diadakannya orientasi bagi pesera didik antara lain peserta didik dapat mengerti dan menaati segala peraturan yang berlaku di lembaga pendidikan tersebut dan agar juga peserta didik siap mengahadapi lingkungan yang baru baik dari segi fisik, mental dan emosiaonal sehingga ia nanti merasa betah dalam mengikuti proses pembelajaran. ${ }^{15}$

Setelah melakukan orientasi kemudian pondok pesantren puteri khadijah pamekasan melakukan evaluasi yang mana dilakukan secara langsung ataupun secara tertulis. Dalam hal ini setiap pelakasanaan kegiatan atau program tentu penting dilaksanakannya sebuah evaluasi, dan pelaksanaan evalusi penerimaan santri baru di PPPK ini dilaksanakan dalam dua bentuk yaitu secara tatap muka langsung melalui rapat dengan pengasuh, seperti menyampaikan hambatan atau permasalahan yang dihadapi selama kegiatan penerimaan santri baru, dan evaluasi yang kedua yaitu berbentuk tertulis seperti LPJ (laporan pertanggung jawaban) kebendaharaan dan kesekretariatan, dimana kebendahaan menyerahkan LPJ-nya kepada pengasuh tentang jalannya keuangan sedangkan kesektariatan melaporkan berapa banyak santri yang mendaftar dan juga mencatat tanggal masuknya santri sampai melaporkan kendala santri yang datang terlambat. Sehingga dengan adanya evaluasi ini akan memberikan arahan atau memberikan perbaikan terhadap program penerimaan santri baru yang akan mendatang.

15 Muhamad Khoirul Umam, "PENINGKATAN MUTU PENDIDIKAN MELALUI MANAJEMEN PESERTA DIDIK," JURNAL AL HIKMAH 6, no. 2 (2018): 65, https://jurnal.staiba.ac.id/index.php/Al-Hikmah/article/view/74/71. 
Jadi pengelolaan sistem informasi dalam penerimaan santri baru di Pondok Pesantren Puteri Khadijah Pamekasan dalam sistem pengelolaannya dapat dikatakan sangat baik hal tersebut dapat dilihat dari perencanaannya yang sangat terperinci yaitu memiliki beberapa tahapan seperti pembentukan panitia penerimaan santri baru, penentuan ditetapkannya kapan tanggal dibukanya pendaftaran hingga ditutupnya pendaftaran santri baru, menentukan syatar-syarat yang dibutuhkan dalam pendaftaran penerimaan santri baru, menyebarkan brosur dengan menggunakan dua metode, menyediakan formulir pendaftaran dan penyetoran berkas-berkas yang berbentuk website, serta melakukan evaluasi yang dilakukan secara langsung ataupun secara tertulis setelah seluruh program terlaksana dengan adanya evaluasi tersebut tentunya untuk mengetahui apa saja yang masih kurang dari kinerja ke panitian penerimaan santri baru kemudian diperbaiki dimasa yang akan datang agar kinerja menjadi lebih baik dari pada sebelumnya.

\section{Faktor Pendukung dan Penghambat Pengelolaan Sistem Informasi dalam Penerimaan Santri Baru di Pondok Pesantren Puteri Khadjah Pamekasan}

Berdasarkan hasil wawancara dan pengamatan yang dilakukan oleh peneliti dapat diketahui bahwa faktor yang mendukung pengelolaan dalam penerimaan santri baru di Pondok Pesantren Puteri Khadijah Pamekasan diantaranya dengan adanya bimbingan dari pengasuh, adanya kerja sama yang baik antara pengasuh dengan panitia penerimaan santri baru dan juga adanya sarana dan prasana yang memadai.

Sebagaimana dalam pertauran pemerintah nomor 19 tahun 2005 tentang standar nasional pendidikan, bahwa setiap satuan pendidikan wajib memilki (1) sarana yang menjadi perabot, peralatan pendidikan, media pendidikan, buku dan sumber belajar lainnya, bahan habis pakai, serta perlengkapan lain yang diperlukan untuk menunjang proses pembelajaran yang teratur dan berkelanjutan. (2) setiap satuan pensisikan wajib memilki prasarana yang melipuiti lahan, ruang kelas, ruang pimpinan satuan pendidikan, ruang pendidik, ruang tata usaha, raung perpustakaan, ruang laboratorium, ruang bengkel kerja, ruang unit produksi, ruang kantin, instlasi daya dan jasa, tempat berolahraga, tempat beribadah, tempat bermian, tempat berkreasi, dan ruang/tempat lain yang diperlukan untuk menunjang proses pembelajaran yang teratur dan berkelanjutan. ${ }^{16}$

Rizlaili Istiqomah dalam jurnal Implementasi Penerimaan Peserta Didik Baru (PPDB) Online di Dinas Pendidikan Kota Surakarta menyatakan bahwa dengan adanya faktor pendukung dalam beberapa hal akan membuat pelaksnaannya menjadi lebih lancar, diantaranya : pertama sumber daya manusia, dalam hal ini sumber daya manusia sangat berperan penting dalam pelaksanaan penerimaan peserta didik untuk dapat menjalankan atau mengoperasikan dengan baik, kedua ketersedian sarana dan prasana yang memadai, dalam hal ini sarana dan prasana ini

16 Peraturan Pemerintah Republik Indonesia Nomor 19 tahun 2005 Tentang Standar Nasional Pendidikan, 13. 
dapat mendukung pelasanaan penerimaan peserta didik agar dapat mencapai tujuan pelaksanaan PPDB tersebut. ${ }^{17}$

Sedangkan temuan penelitian di lapangan faktor pendukung dalam penerimaan santri baru di pondok pesantren puteri khadijah pamekasan yaitu adanya dengan adanya bimbingan dari pengasuh mengenai perencanaanperencanaan yang akan dilakukan serta diterapkan bagi kepanitian penerimaan santri baru. Sebagaimana pengasuh dan kepanitian ini merupakan sumber daya yang sangat berperan penting dalam proses berjalannya penerimaan santri baru ini. Selain itu juga adanyakerja sama yang baik antara pengasuh dengan panitia penerimaan santri baru serta adanya sarana dan prasana yang memadai yang sudah disediakan oleh Pondok Pesantren Puteri Khadijah Pamekasan.

Berdasarkan hasil wawancara dan pengamatan yang dilakukan oleh peneliti dapat diketahui bahwa faktor penghambat dalam penerimaan santri baru di Pondok Pesantren Puteri Khadijah Pamekasan yaitu kurangnya kekompakan sesama panitia penerimaan santri baru, dan kurangnya komunikasi jalanin komunikasi yang baik antar panitia PSB.

Sedangkan temuan penelitian di lapangan faktor pendukung dalam penerimaan santri baru di pondok pesantren puteri khadijah pamekasan yaitu ada salah satu dari wali santri yang merasa tidak mampu untuk membayar uang pembayaran pendaftran, sehingga hal tersebut menjadi faktor penghambat dalam berjalannya penerimaan santri baru, kurangnya kekompakan sesama panitia penerimaan santri baru, kurangnya komunikasi jalanin komunikasi yang baik antar panitia PSB.

Jadi faktor Pendukung dan Penghambat Pengelolaan Sistem Informasi dalam Penerimaan Santri Baru di Pondok Pesantren Puteri Khadjah Pamekasan yaitu dengan adanya bimbingan dari pengasuh mengenai perencanaan-perencanaan yang akan dilakukan serta diterapkan bagi kepanitian penerimaan santri baru, adanya kerja sama yang baik antara pengasuh dengan panitia penerimaan santri baru serta adanya sarana dan prasana yang memadai yang diberikan oleh Pondok Pesantren Puteri Khadijah Pamekasan. Sedangkan untuk faktor penghambatnya, ada salah satu wali santri yang ingin membayar secara nyicil padahal sudah jelas pada peraturan yang tertera mengenai pembayaran tersebut bahwa pembayaran itu harus bayar langsung, terkadang antara sesama panitia ada perbedaan pendapat sehingga kelancaran dalam pelaksanaan penerimaan santri baru mengalami kendala, terjadinya miskomunikasi antara pengurus dan panitia penerimaan santri baru, seperti yang kita ketahui bahwa jalinan komunikasi antar kepanitian merupakan hal yang sangat penting terhadap sukses atau tidak suksesnya suatu acara.

\section{KESIMPULAN}

Berdasarkan penelitian yang telah dilakukan yang berjudul "Pengelolaan sistem informasi dalam penerimaan santri baru di Pondok Pesantren Puteri Khadijah Pamekasan". Dapat ditarik kesimpulan berupa:

17 Rizlaili Istiqomah, Kristiani, and Budi Wahyono, "Implementasi Penerimaan Peserta Didik Baru (PPDB) Online Di Dinas Pendidikan Kota Surakarta," BISE: Jurnal Pendidikan Bisnis Dan Ekonomi 4, no. 2 (2018): 8, https://jurnal.fkip.uns.ac.id/index.php/ptn/article/view/12165/8662. 
Pengelolaan sistem informasi dalam penerimaan santri baru di Pondok Pesantren Puteri Khadijah Pamekasan yaitu pengelolaan sistem informasi dalam penerimaan santri baru di Pondok Pesantren Puteri Khadijah Pamekasan dalam sistem pengelolaannya sangat terperinci serta terencana dengan baik hal tersebut dapat dilihat dari perencanaan yang memiliki beberapa tahapan seperti pembentukan panitia penerimaan santri baru, penentuan ditetapkannya kapan tanggal dibukanya pendaftaran hingga ditutupnya pendaftaran santri baru, menentukan syatar-syarat yang dibutuhkan dalam pendaftaran penerimaan santri baru, menyebarkan brosur dengan menggunakan dua metode, menyediakan formulir pendaftaran dan penyetoran berkas-berkas yang berbentuk website, serta melakukan evaluasi yang dilakukan secara langsung ataupun secara tertulis setelah seluruh program terlaksana dengan adanya evaluasi tersebut tentunya untuk mengetahui apa saja yang masih kurang dari kinerja ke panitian penerimaan santri baru kemudian diperbaiki dimasa yang akan datang.

Faktor Pendukung dan Penghambat Pengelolaan Sistem Informasi dalam Penerimaan Santri Baru di Pondok Pesantren Puteri Khadjah Pamekasan yaitu dengan adanya bimbingan dari pengasuh, arahan dari pembina dan juga kerja sama panitia penerimaan santri baru. Yang menjadikan faktor pendukung juga dengan tersedianya sarana dan prasana yang ada di pondok pesantren puteri khadijah serta kerja sama antara pengasuh dengan panitia PSB merupakan faktor penentu terhadap sukses atau tidaknya dari pendaftaran penerimaan santri baru yang dilakukan oleh pondok pesantren puteri khadijah Pamekasan. Sedangkan yang menjadi faktor kurangnya komunikasi antar sesama panitia PSB sedangkan komunikasi merupakan hal yang dapat diatakan sangat penting juga dikarenakan tanpa komunikasi yang baik antar sesama panitia PSB maka nantinya akan terjadi miskomunikasi yang tentunya akan berakibat fatal terhadap kesuksesan acara yang digelar tersebut.

Saran ini lebih di tujukan kepada pengurus kepanitiaan dalam penerimaan santri baru agar lebih ditingkatkan lagi masalah jalinan komunikasi antara sesama kepanitian yang bertugas pada pendaftaran penerimaan santri baru agar tidak terjadi miskomunikasi, ketika berbicara masalah kepanitian tentunya dibutuhkan kerja sama yang baik serta komunikasi yang baik antara sesama panitia yang bertugas demi untuk kelancaran sebuah acara, mengingat ke panitian merupakan faktor penentu terhadap sukses atau tidaknya sebuah acara yang dilakukan.

\section{DAFTAR PUSTAKA}

Athoilla, Anton. Dasar-Dasar Manajemen. Bandung: CV Pustaka Setia, 2010.

Hamdan, Hamdan. "Pengelolaan Santri Di Sekolah Menengah Atas Pondok Pesantren Modern Al-Ikhlas Lubuklinggau." Journal Of Administration and Educational Management (ALIGNMENT) 1, no. 2 (2018): 102-14. https://doi.org/10.31539/alignment.v1i2.346.

Helmawati. Sistem Informasi Manajemen Pendidikan Agama Islam. Bandung: Remaja Rosdakarya, 2015.

Hutahaen, Jeperson. Konsep Sistem Informasi. Yogyakarta: Deepublish, 2015.

Istiqomah, Rizlaili, Kristiani, and Budi Wahyono. "Implementasi Penerimaan Peserta Didik Baru (PPDB) Online Di Dinas Pendidikan Kota Surakarta." BISE: Jurnal Pendidikan Bisnis Dan Ekonomi 4, no. 2 (2018): 1-12. https://jurnal.fkip.uns.ac.id/index.php/ptn/article/view/12165/8662. 
Jahari, Jaja, and Heri Khoiruddin. "Manejemen Peserta Didik." Jurnal ISEMA (Islamic Education Management) 3, no. 2 (2018): 170-80. https://journal.uinsgd.ac.id/index.php/isema/article/view/5009/2789.

Juju Saepudin. "PENDIDIKAN AGAMA ISLAM PADA SEKOLAH BERBASIS PESANTREN: STUDI KASUS PADA SMP AL MUTTAQIN KOTA TASIKMALAYA." EDUKASI: JURNAL PENELITIAN PENDIDIKAN AGAMA DAN KEAGAMAAN 17, no. 2 (2019): 172-87. http://jurnaledukasikemenag.org.

Moleong, Lexy J. Metodologi Penelitian Kualitatif. Bandung: Remaja Rosdakarya, 2016.

Mubah, Hilmi Qosim. Manajemen Pesantren Dan Pendidikan Luar Sekolah. Pamekasan: iainmadura press, 2019.

Priansa, Donni Juni. Manajemen Dan Supervisi Pendidikan. Bandung: CV. Pustaka Setia, 2018.

Setiawan, Ahmad Bagus, and Juli Sulaksono. "Sistem Informasi Manajemen Santri Di Pondok Pesantren Al Ishlah Kota Kediri." Network Engineering Research Operation 4, no. 2 (2019): 81-86. https://doi.org/10.21107/nero.v4i2.122.

Umam, Muhamad Khoirul. "PENINGKATAN MUTU PENDIDIKAN MELALUI MANAJEMEN PESERTA DIDIK.” JURNAL AL HIKMAH 6, no. 2 (2018). https://jurnal.staiba.ac.id/index.php/Al-Hikmah/article/view/74/71.

Wibowo, Adi. "INTEGRASI MANAJEMEN KESISWAAN PENDIDIKAN FORMAL DAN NON FORMAL DI PONDOK PESANTREN AN-NAWAWI BERJAN PURWOREJO.” Jurnal ISEMA (Islamic Education Management) 4, no. 2 (2019): 221-28.

Yulianeu, Aneu, and Muhamad Sodik. "Perancangan Sistem Informasi Penerimaan Santri Baru Di Pondok Pesantren Sukamanah." Jurnal Manajemen Informatika 6, no. 2 (2019): 21-30. 